\title{
The Applicability of the Learning School Model of Strategy Formulation (Strategy Formulation as an Emergent Process)
}

\author{
Isaac Quaye1, Abraham Osei1, Alfred Sarbah1, Eugene Abrokwah² \\ ${ }^{1}$ School of Management \& Economics, University of Electronic Science \& Technology of China, Chengdu, China \\ ${ }^{2}$ School of Business, University of Shanghai for Science and Technology, Shanghai, China \\ Email: sarbah@yahoo.com, mrquaye2000@gmail.com
}

Received 12 February 2015; accepted 27 March 2015; published 31 March 2015

Copyright (C) 2015 by authors and Scientific Research Publishing Inc.

This work is licensed under the Creative Commons Attribution International License (CC BY).

http://creativecommons.org/licenses/by/4.0/

c) (i) Open Access

\begin{abstract}
Great strategies are worth nothing if they cannot be implemented [1]. It can be extended to say that better to implement effectively a second grade strategy than to ruin a first class strategy with ineffective implementation [2]. Thus, effective implementation of strategies is important to the success of every entity. There are many ways of classifications of strategy. However, there are ten schools of thought that dominate recent thinking on strategy. These ten schools or models of strategy formulation were proposed by Henry Mintzberg, Bruce Ahlstrand and Joseph Lampel in their book "Strategy Safari: A Guided Tour through the Wilds of Strategic Management". The "learning school" is one of these schools. From the perspective of this school, there is the emergence of strategies as people act individually but most of the time through concerted efforts, learning about a phenomenon as well as their entity's competence in dealing with it. There are criticisms of this model saying there is the danger of going to the opposite extreme which may result in no strategy, lost strategy or wrong strategy. However, the study provides insight into the adoption and application of this strategy as well as the enormous benefits that accrue to learning organizations. The authors, having reviewed a vast number of literature, have summarized the concept of the learning school as "all hands-on-deck phenomenon" where individuals or employees are empowered in teams to improve their desire and ability to create and explore what they want in order to understand and manage the organization and its task environment.
\end{abstract}

\section{Keywords}

Learning School, Strategy Formulation, Emergent Process, Strategic Management

How to cite this paper: Quaye, I., Osei, A., Sarbah, A. and Abrokwah, E. (2015) The Applicability of the Learning School Model of Strategy Formulation (Strategy Formulation as an Emergent Process). Open Journal of Business and Management, 3, 135-154. http://dx.doi.org/10.4236/ojbm.2015.32014 


\section{Introduction}

The business environment today is rapidly changing and organizations are developing new and innovative ideas to help achieve most if not all its objectives. The objectives differ from one organization to another which range from profit maximization, shareholders wealth maximization, customer satisfaction, growth and survival, cooperate social responsibility among others.

These objectives cannot be achieved effortlessly. They need concerted efforts by the owner(s) of business organizations and others through well designed and thought-through plans. These plans are carried out through an integrated and coordinated set of commitments and actions known as strategy. Thus, strategies must be analyzed, formulated and implemented well to achieve a desired outcome or earn above average returns. The process of analysis, formulation and implementation of strategy is called strategic management. The use of strategy has existed for many centuries although its use in management has been a more recent history, dating back about 40 years.

Strategy was borne out of military conflicts and the use of a superior strategy enabled one warring party to defeat another [3]. Von Clausewtz, writing in the nineteenth century, states that the decision to wage war out to be rational, that is based on estimates of what can be gained and the cost incurred by the war [4]. War should also be instrumental, that is waged to achieve some specific goal, never for its own sake, and that strategy should directed to achieve one end, in this case, victory. Thus, strategy is simply an outline of how a business intends to achieve its goals.

The use of strategy in decision-making is the primary way in which managers take into account of a constantly changing external environment. An effective strategy allows them to use their organization's resources and capabilities to exploit opportunities and limit threats in the external environment in order to achieve competitive advantage. A debate arises when we try to pin down "what strategy is" and, importantly, "how is strategy formulated?” This discussion has continued for decades and is rooted in a desire for managers to undertake better strategic thinking and therefore better strategic decisions [3].

Strategy can be defined in a number of different ways. Strategy is defined as the process of trying to understand what a business is about in its close environment and a continual reviewing and revisiting of the assumptions that are made within the organization about its purposes and functions [5]. The content and context of any strategy will usually be unique, but the strategy process can be defined as being based on three phases: analysis, formulation and implementation [6] as depicted in the Figure 1 below.

The creation of strategy is the most important responsibility of senior executives [7]. It is therefore worrying that very few executives can summarize their company's strategy in 35 words or fewer [8]. Competitive advantage is the essence of strategy, and what a business does differently from or better than others defines the all-important means by which the business achieves its stated objective. This objective needs to be precise, as it will drive the business over the next five years or so. The goal of any company should therefore be to have a simple strategy statement that is unique, in that it could not belong to any other firm [9]. Although formulating a consistent strategy is a difficult task for any management team, making that strategy work and implementing it

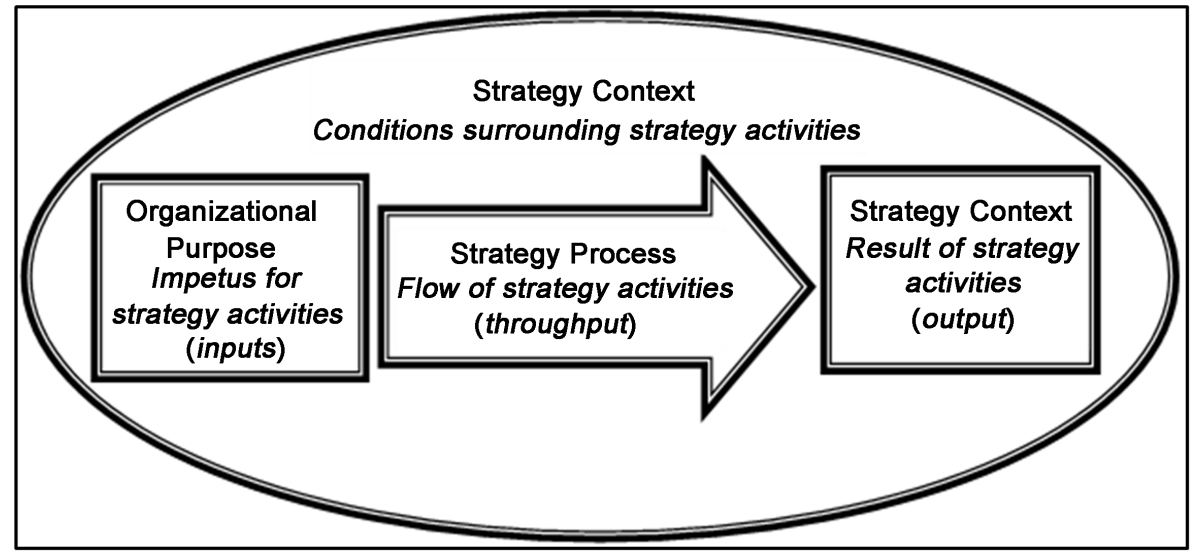

Figure 1. Strategy context, process and content, linked to organizational purpose. Source: De Wit, B. and Meyer, R. (2004). 
throughout the organization is even more difficult [10]. A myriad of factors can potentially affect the process by which strategic plans are turned into organizational action. Unlike strategy formulation, strategy implementation is often seen as something of a craft, rather than a science, and its research history has previously been described as fragmented and eclectic [11].

It is thus not surprising that, after a comprehensive strategy or single strategic decision has been formulated, significant difficulties usually arise during the subsequent implementation process. The best-formulated strategies may fail to produce superior performance for the firm if they are not successfully implemented [12]. Without execution even the most brilliant strategy is useless. Being successful requires skills and knowledge to carry out strategic decisions and plans. Since the 1970s research on strategy processes has been addressing this challenge by examining the processes of strategy formulation and implementation [13]. The main topics of strategy process research have been strategic decision making [14]-[17], incremental strategy formation [18]-[20], and organizational politics [21]. There are many ways of formulation of strategy by different authors and available literature. However, the authors of this paper find Henry Mintzberg, Bruce Ahlstrand and Joseph Lampel's ways of formulation of strategy as one that is in line with the main aim of this paper which examines the application of the learning school model of strategy formulation to organizations. Mintzberg, Bruce Ahlstrand and Joseph Lampel came up with ten (10) ways or schools of formulation of strategy which include the learning school of strategy formulation. According to the learning school, strategy in an organization emerges as a result of trial and error learning within an organization. It recognizes that strategy must be consonant with the patterns of behavior and response that are inherent within an organization. In each of the ten (10) schools, the process of strategy formulation itself is regarded as something of a "black box"-none of them are able to clearly describe how an individual or group is able to leap from the collection and analysis of information, to the conceptualization of alternative courses of action (although they do concede that the cognitive school comes closest). Overall, the authors appear to prefer the "learning school" because of the emphasis that it places on an organization incorporating input from its environment, and adapting over time [22]. The remainder of this paper is structured as follows: Sections 2 and 3 present classification of strategy and model's foundation respectively. The origin, premises and the ideas of the learning school are covered in Sections 4, 5 and 6 respectively. Section 7 presents how the learning school model will be applied in organizations while Sections 8 and 9 cover the criticisms \& limitations and contributions of the learning school respectively. The success story of Honda is used as case study to illustrate how organizations benefit from applying the learning school model. This is presented in Section 10. The conclusion of this paper is presented in Section 11.

\section{Classifications of Strategy}

A number of classifications of strategy exist, all of which attempt to classify strategy into groupings or schools representing different approaches, philosophies or even language-usage [9]. In 1993, Whittington organized strategy into four broad groupings namely Classical, Evolutionary, Processual and Systemic along two dimensions - whether companies aim for profit maximizing or pluralistic outcomes, and whether strategy is deliberate or emergent [23] as shown in Figure 2 below.

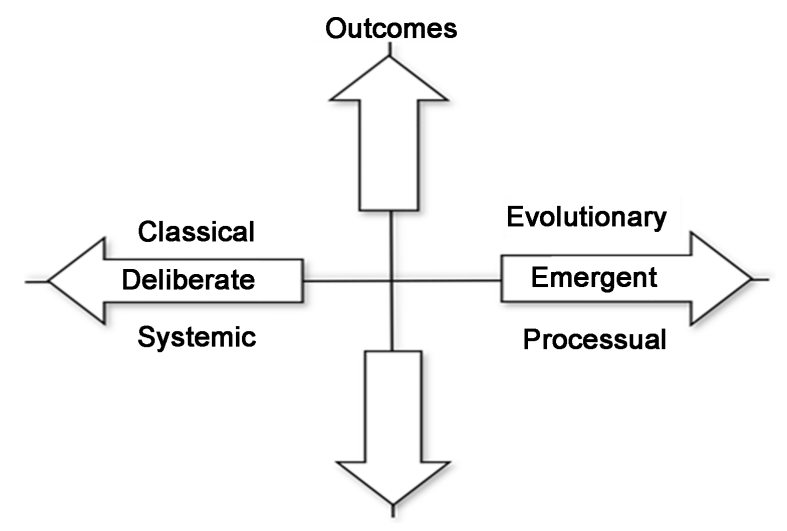

Figure 2. Whittington's four generic approaches to strategy. Source: Whittington, R. (1993). 
Strategy can also be divided into two main groups namely neoclassical and socio-ecological [24]. The competitive activity among firms is the emphasis of neoclassical approaches [25]-[28]. On the contrary, the socioecological point of view emanated in Tavistock approaches to open systems theory [29]. Another famous and comprehensive classification of strategy is Mintzberg's categorization of strategy formation into ten schools [30]. These ten schools have recently been refined, described and critiqued extensively [31]. The correlation between the ten dominant strategy schools is shown in Figure 3 [32] whiles Table 1 names these schools and matches them with the type of process most closely associated with each, and with the overall tone-is it: prescriptive (instructing us how strategy should look); descriptive (outlining how it actually looks and works in practice); or integrative (trying to join all the different approaches together and find a role for each) [9]?

The world of strategy is perceived by the cognitive school as really a complex one and therefore overwhelms the prescriptions of the design, planning, and positioning schools. Then the question is "how are strategists supposed to proceed?” They learn over time [31]. This is the focus of the learning school.

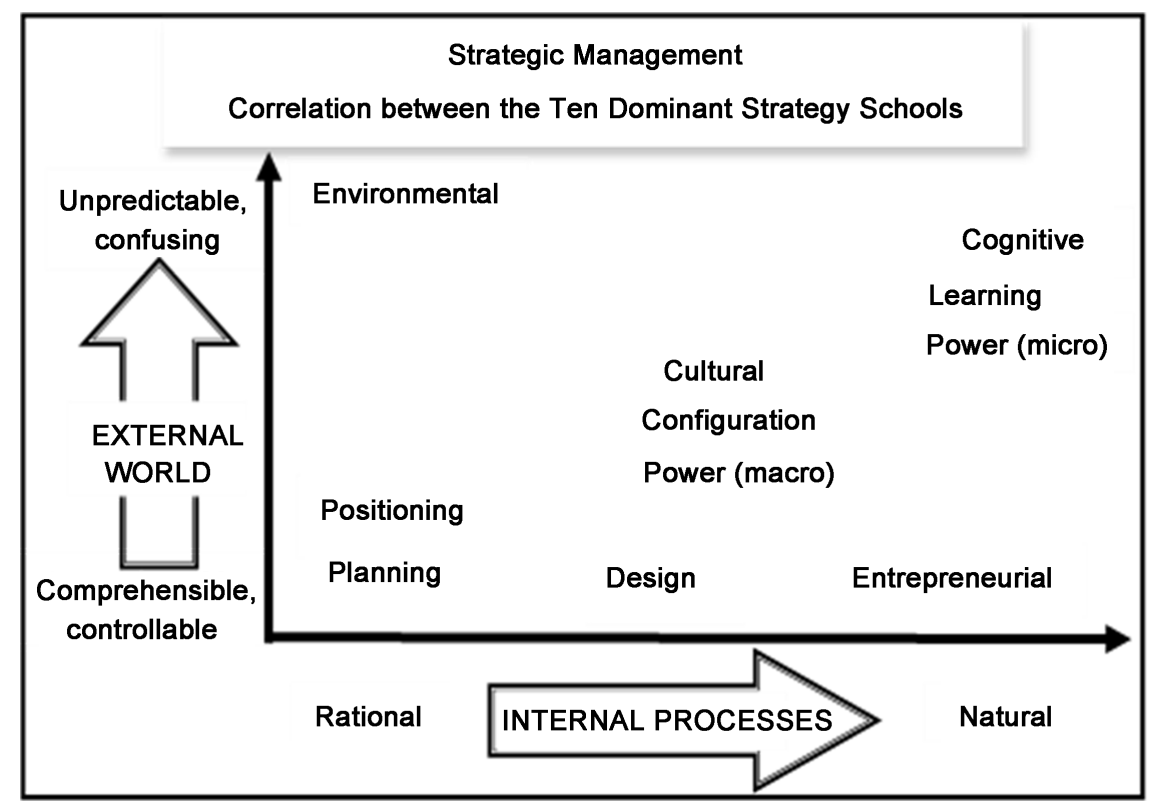

Figure 3. Correlation between the ten dominant strategy schools. Source: “Strategy Safari”, Mintzberg, Ahlstrand and Lampel (1998).

Table 1. The ten schools of thought.

\begin{tabular}{ccc}
\hline School & Type of process & Tone \\
\hline Design & Conception & Prescriptive \\
Planning & Formal & Prescriptive \\
Positioning & Analytical & Prescriptive \\
Entrepreneurial & Visionary & Descriptive \\
Cognitive & Mental & Descriptive \\
Learning & Emergent & Descriptive \\
Power & Negotiation & Descriptive \\
Cultural & Collective & Descriptive \\
Environmental & Reactive & Descriptive \\
Configuration & Transformation & Integrative \\
\hline
\end{tabular}




\section{Model's Foundation}

The process comprises critically examining what works and what does not work for the organization gradually in the day-to-day running of the organization. Learning before implementing theory-use of experience in making decisions forms the basis of this model. Strategy is created as strategists learn over time. There is always the integration of the lessons learned out of the experience and monitoring into the overall action plan of the organization. Proponents of the school postulate that the world is too sophisticated for strategies to develop in a pop up mode and have them implemented as clear visions and plans. Therefore, the learning school is of the view that strategies must emerge gradually over time which will allow organizations to learn and adapt. Organizations are must learn and apply. They could re-try the same or something else if they do not succeed. Therefore, strategic management becomes "no longer just the management of change but the management by change" [33] [34]. The learning school has been modelled graphically in Figure 4.

\section{Origin of the Learning School}

This school was originated by Charles Lindblom in 1959 in his publication “The Science of Mudding Through”. He put forward that there is no neat, orderly and controlled process of policy making in government because of the complex nature of the world [35]. Every basis of management may have almost been contravened by Lindblom's concepts. However, they seem significant as behaviors accustomed to individuals and in businesses are been described as his Lindblom's concepts were not only peculiar to governments. Some authors followed with similar school of thought including H. Edward Wrapp who published an article “Good Managers Don't Make Policy Decisions" in 1967. He postulated that things are not what most people believe them to be in the

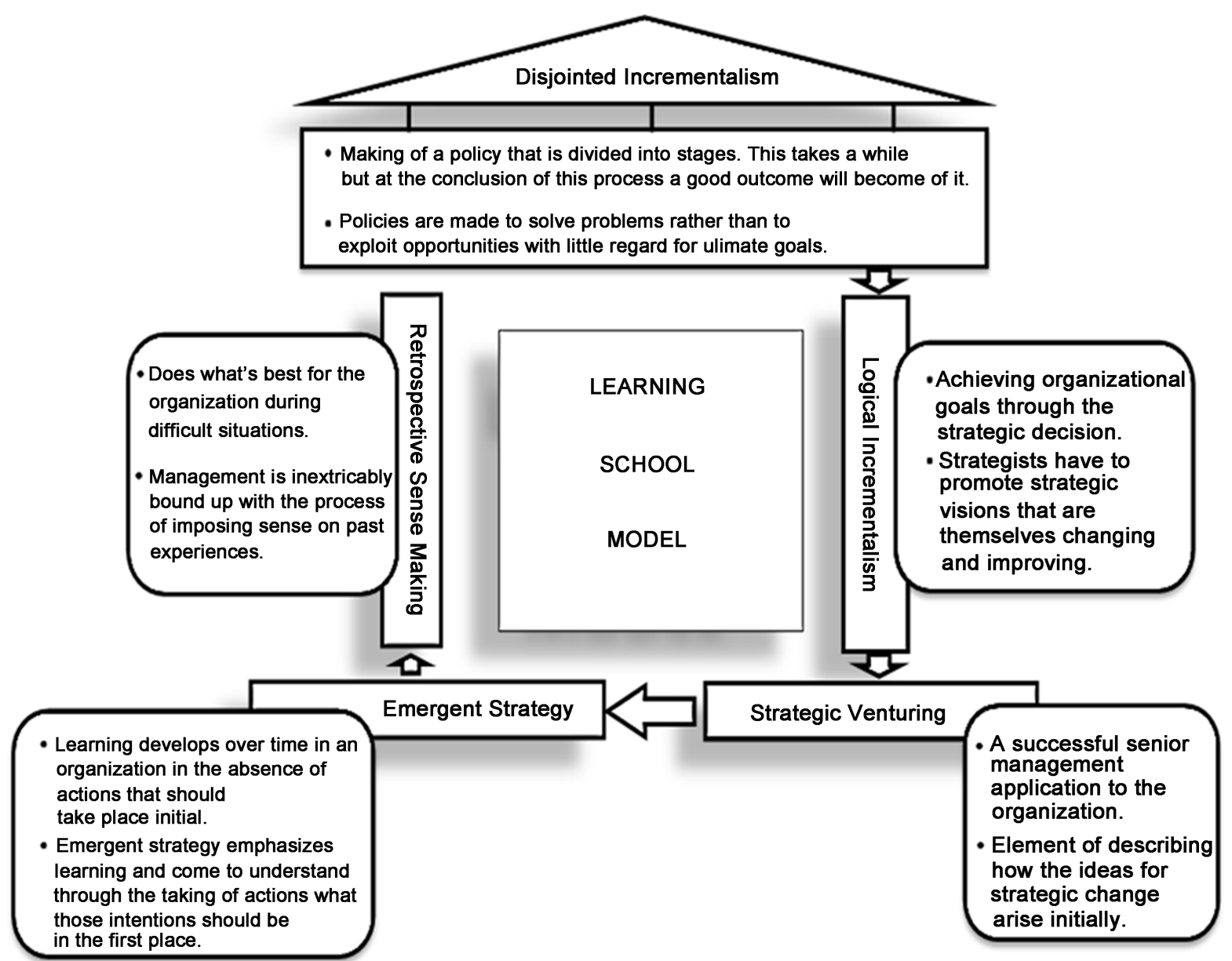

Figure 4. Learning school model. Source: Authors’ construct. 
top management world. Top managers do not spend most of their time making broad policy decisions, formulating objectives, conceptualizing long-range plans or meditating on the role of his organization in society [36]. However, the learning school gained grounds in the 1980s when James Brain Quinn published a book titled “Strategies for Change: Logical Incrementalism”. Since then vast number of literature have emerged and entered the mainstream of current strategic management [20].

\section{Premises of the Learning School}

The following premises can be identified from the vast collection and review of available literature associated with the learning school of strategy formulation [33]:

- The complex and unpredictable nature of the organization's environment, often coupled with the diffusion of knowledge bases necessary for strategy, precludes deliberate control; strategy making must above all take the form of a process of learning over time, in which, at the limit, formulation and implementation become indistinguishable.

- While the leader must learn too and sometimes can be the main learner, more commonly it is the collective system that learns: there are many potential strategists in most organizations.

- This learning proceeds in emergent fashion, through behavior that stimulates thinking retrospectively, so that sense can be made of action.

- The role of leadership thus becomes not to preconceive deliberate strategies, but to manage the process of strategic learning, whereby novel strategies can emerge.

- Accordingly, strategies appear first as patterns out of the past, only later, perhaps, as plans for the future, and ultimately, as perspectives to guide overall behavior.

\section{Ideas of the Learning School}

Learning school is the most complex of the descriptive schools. Learning school is initiated from incrementalism, a working method, based on the chain of small, sometimes unplanned, projects. The method deploys a stepby-step approach, with many small changes over a period of time. Such changes serve to the purpose to create one significant change. The school evaluates strategy as “an emerging process” where stakeholders learn the situation and organization's capability in reaction to different aspects. Burgelman contributed to the learning school by evaluating top executives, managers and operating managers in terms of their values [37]. Noda and Bower in 1996 summarized the "Bower-Burgelman Process Model of Strategy Making” as involving “multiple, simultaneous, interlocking, and sequential managerial activities over three levels and involving four sub-processes: two interlocking bottom-up core processes of 'definition' and 'impetus' and two overlaying corporate processes of ‘structural context determination' and 'strategic context determination'” [38]. This model is shown in Burgelman's version in Figure 5 [39].

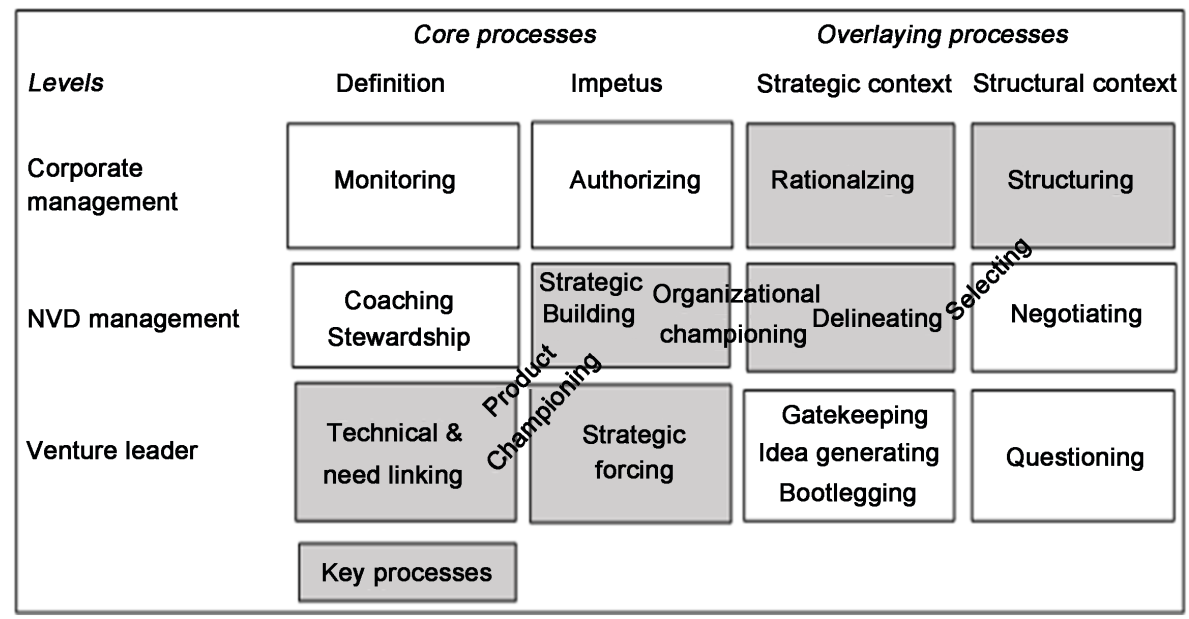

Figure 5. Burgelman's process model of internal corporate venturing (ICV). Source: Burgelman (1983a). 
The idea of learning may be simple itself, but it is not that simple to be implemented. The central point of the school is that it values individual and collective knowledge, experience, and efforts to contribute toward strategy formation. People learn about situations and organization's capability to manage them by maintaining specific behavior. Such behavior can be transformed into strategy [20]. In a related publication by Pelling in 2004, he postulates that, strategy is a network of knowledge where "people continue to develop in respond to anomalies" [40]. He further states that the learning school replaces formal "formulation-implementation" process with "acting-learning” process, but does not specify how it is controlled. Pelling's arguments were that the school focuses on the experience, but there is a clear explanation on how to differentiate good practice from bad practice. Learning school incorporates several "streams of inquiry" and logic vision [20]. Pelling's approach was criticized by Mintzberg as "unclear or ambiguous" because it is not obvious whether a strategy is formed together with a strategic vision or whether such vision is developed before strategy formulation, by the strategy developer and through consolidating "previous successful attempts to strategic change" [41].

There are different ways by which the process of learning can go. It can be done either through diversification, as in case of Philip Morris, or through mistakes, as in case of Honda. The key concept about the learning school is that, in complex and unpredictable environment, strategy must have a process of learning over time. Leaders must have an opportunity to learn within an organization, and their role is to manage the process of strategic learning. The learning can be processed through evaluating organizational behavior that stimulates thinking. The strategic management process is informal and acts out of individual decision. Anybody can promote ideas or initiatives. In this perspective, leaders' role is to respond to these initiatives, to manage the process of strategic learning [37]. The concept was developed by Lindblom through theoretical policy of rationality [42] and the notion of "venturing emerging strategy" together with "retrospective sense making". In fact, Sandlberg named Lindblom's “The Science of Muddling Through" (1959) and Quinn's "Strategies for Change” (1980) as the most influential works in the formation of learning school [43].

Learning school elaborates on Quinn's definition of “underlying logic”, who consolidated all previous successful strategic models or actions in a visible and articulated manner, in a way that was understood or made sense to him. Quinn developed a mechanism that would lead to successful emergent strategy. Bureglman's research partially contributed to this process of development. The school authentically challenges prescriptive schools. It shares the ideas of emergent strategy and "Weick's notion of retrospective sense making" [44], the concept that strategy is formed together with learning, through behavior of retrospective thinking. For learning school, strategy is the emerging process of learning about the context and organization's capability. The process involves both individuals and group of people. Thus the school approach on strategy formation is through learning and practice. For instance, organization can learn through evaluating the pattern of its own behavior or by entering new markets and see what is organizational strengths and weaknesses under particular terms and conditions. As part of such learning process, Mintzberg developed an expanded vision of the umbrella strategy, applicable to overall perspective and to its particular areas [37].

Research by Steven French critically examines the theory of business strategy through testing a small business strategic process. French created hypotheses for the learning school: "strategy is developed by a process of organizational learning" and "the cybernetic paradigm is stretched to accommodate non-linear ideas of learning, innovation, and emergence" [45]. French believes that the learning school changes "from a modernist/postmodernist classical linear paradigm to one that is complex and self-adapting". French argues that the system is dynamic and tends to transform "non-linear phenomena in a cybernetic context and postmodern ideas" into postmodernism. Thus, strategic learning is not fit to the cybernetic organizations. French refers to publication by Eijnatten and Putnik in 2004, who evaluate the issue through developing "the ideas of organizational learning" and shift them "from a traditional linear paradigm to a complex, dynamic, non-linear environment" [46]. This creates an entity that can be viewed as a final state of a learning organization, if the organization is self-organized and transformative "under hyper-turbulent conditions". Such self-organized structure with its behavioral rules can change the paradigm from modern/postmodern to critical. However, French reports that such vision is not accepted by the learning school.

\section{Application of Learning Strategy to Organization (The Learning Organization)}

Managers of businesses and non-profit organizations as well as the worlds of education at large view the concept of learning organization as great importance in recent years. Fundamentally, the dominant "bureaucratic" para- 
digm that has existed at the core western civilization for some 200 years has been challenged by the principles of the learning organization [47]. Learning organization concept places emphasis on managers to be interested as never before in the process of learning, as well as the results. The focal point of the learning organization has two aspects: 1) that a key success factor for any business in the age of global competition is its ability to innovate continuously, appropriately, and faster than its rivals, and 2) that can only happen through unleashing the untapped capabilities of all its employees [48]. Corporations in an attempt to gain competitive edge better themselves continuously to improve their programs. However, successful programs are lesser than failed ones and lower improvement rates recorded. The accounting factor for such massive program failures is that most companies have failed to recognize a basic principle that people must learn first before they can improve. In order for this to materialize, priority must be given to the fundamentals instead of concentrating on rhetoric and high philosophies. David Garvin, Harvard Business School Professor, in 1993 cites three critical issues that must be addressed before a company can truly become a learning organization [49]:

- First is the question of meaning: a well-grounded, easy-to-apply definition of a learning organization.

- Second comes management: clearer operational guidelines for practice.

- Finally, better tools for measurement can assess an organization's rate and level of learning.

He further states that no learning organization is built overnight. In his view, success comes from carefully cultivated attitudes, commitments, and management processes that accrue slowly and steadily. Therefore, the first step is to foster an environment conducive to learning.

Learning organization has been defined differently by various authors and researchers. However, the concept of learning organization became very famous in the 1990s when Senge defined learning organizations as "places where people continually expand their capacity to create the results they truly desire, where new and expansive patterns of thinking are nurtured, where collective aspiration is set free, and where people are continually learning how to learn" [50]. He suggested five sets of characteristics called "component technologies" to achieve this result: systems thinking, personal mastery, mental models, shared vision and team learning. A new definition was proposed by David Garvin based on the ideas propounded by Senge. David Garvin defined learning organization as "an organization skilled at creating, acquiring and transferring knowledge, and at modifying its behavior to reflect new knowledge and insights" [49]. According to David Garvin, learning organizations have to carry out five activities: systematic problem solving, experimentation with new approaches, learning from their own experience and past history, learning from the experiences and best practices of others, and transferring knowledge quickly and efficiently throughout the organization. Garvin stressed the idea that each activity has to be managed as a system, which includes a mind-set, a set of mechanisms and a pattern of behavior. This idea is very similar to the "organic system view" of the core capabilities and the four subsystems described by LeonardBarton [51] [52]. Only if learning is managed deliberately across the different activities, can the organization be a "learning organization" and continually keep competitive advantage. Companies have to actively manage the learning process to ensure that it occurs by design rather than by chance [53].

The definition by David Garvin starts with a simple principle: new ideas form the pivot of learning process. Companies or organizations that do pass this definitional test have, by contrast, become adept at translating new knowledge into new ways of behaving. Examples of such companies are Honda, Corning, and General Electric. In these organizations, many key strategic issues come under the direct control of individual professionals, while others can be decided neither by individual professionals nor by central managers, but instead require the participation of a variety of people in a complex interactive process. As illustrated in the accompanying Figure 6, the decisions controlled by individual professionals, by central managers, and by the collectivity are examined below [31] [54]:

\section{1) Decisions Made by Professional Judgment}

Professionals who work in government, business, the legal system, medicine, and many other settings make critically important decisions every day [55]. Decision making in organizations are trusted into the hands of individuals as professionals. Professionals are left to decide on their own only because years of training have ensured that they will decide in ways generally accepted in their professions. Individual freedom becomes professional control when pushed to the limit. Professional judgment is emphasized to imply that while judgment may be mode of choice, it is informed judgment, basically influenced by professional training and affiliation. Decisions taking here include:

- determination of basic mission

- identification of specific services to be offered and to whom 


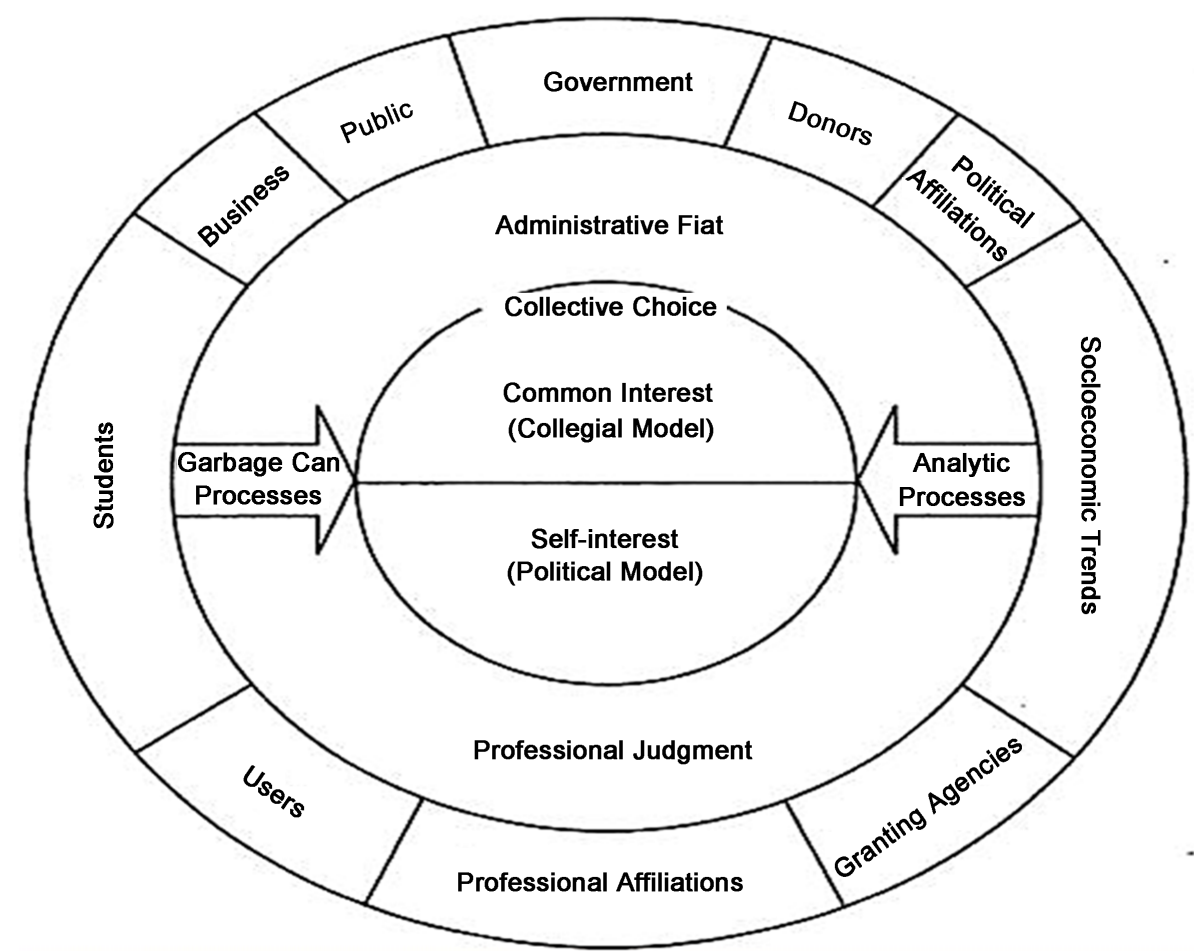

Figure 6. Three levels of decision-making in the professional organization. Source: Mintzberg et al. (1998).

\section{2) Decisions Made by Administrative Fiat}

Professional autonomy sharply circumscribes the capacity of central managers to manage the professionals in the ways of conventional hierarchy. But certain types of activities do fall into the realm of what can be called administrative fiat. In order words, they become exclusive prerogative of the administrators. They include:

- taking financial decisions

- controlling many of the non-professional workers

- determining the procedures by which the collective process functions (what committees exist, who gets nominated to them, etc.)

\section{3) Decisions Made by Collective Choice}

Many decisions are handled in interactive processes that combine professionals with managers and administrators from a variety of levels and units. The decision making process tend to be a fully interactive process involving several layers of standing committees composed of professionals and administrators. It may sometimes involve outsiders such as government representatives. Decisions taking here include:

- creation and discontinuation of the activities and units of various kinds

- hiring and promotion of the professionals

- budgeting

- establishment and design of interactive procedures

\subsection{Three Major Thrusts Related To Learning Organization}

\subsubsection{Learning as Knowledge Creation}

The ability to create new knowledge is often at the heart of the organization's competitive advantage. Sometimes this issue is not treated as part of knowledge management since it borders and overlaps with innovation management [56]. Some scholars have tried to simplify knowledge transfer and creation [57]-[61]. However, Nonaka in 1994 argued that knowledge can be created, shared, improved, and justified via collaborative, social processes and individual's cognitive processes such as reflection [62] [63]. Knowledge creation according to the Nonaka's SECI (Socialization, Externalization, Combination and Internalization) model as depicted in Figure 7 is about continuous transfer, combination, and conversion of the different types of knowledge, as users practice, 


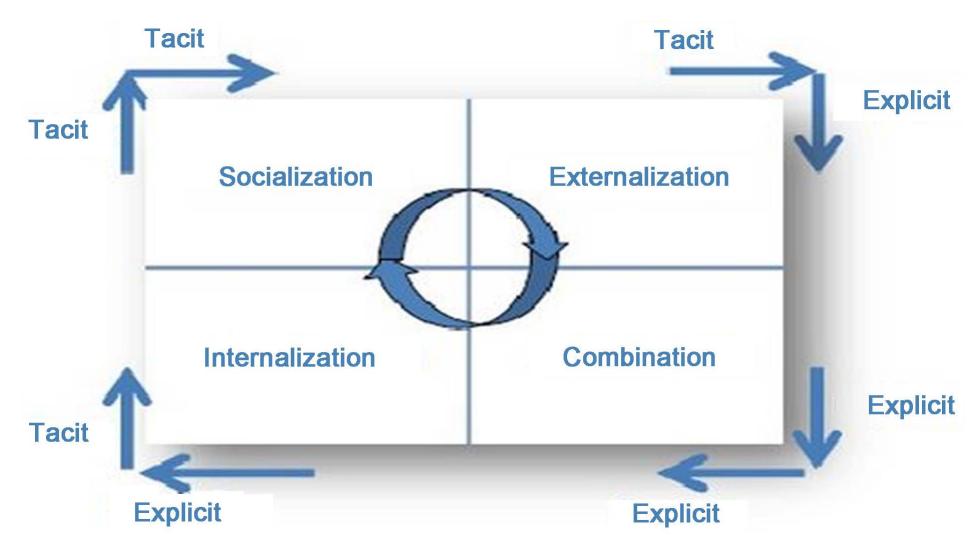

Figure 7. The spiral of knowledge. Source: Adapted from Nonaka and Takeuchi (1995: 71).

interact, and learn [64]. In order to join the process of individual and organizational learning together, a systemic and systematic management of organizational knowledge is helpful [65]. Human knowledge can be categorized into two simple types: tacit and explicit knowledge [58] [66]. The key function of the effective knowledge-creating process depends on the interactions between these two types of knowledge, a process called knowledge conversion [58] [62] [67]. The knowledge conversion process has four modes: 1) socialization (from tacit to tacit, 2) externalization (from tacit to explicit), 3) combination (from explicit to explicit), and 4) internalization (from explicit to tacit). Figure 8 summarizes all four phases with key actions of each phase [68] [69].

\subsubsection{The Dynamics of Organizational Capabilities}

Firms increasingly operate in a dynamic environment. To stay competitive in such an environment firms have to develop organizational capabilities and know-how that enables them to deal with core organizational problems. The concept of organizational capabilities understands organizational change as a continuous and open-ended process of organizational development [70]. Dynamic capabilities are linked to "the firm's ability to integrate, build and re-configure internal and external competencies to address rapidly changing environments" [71]. In 1995, Leonard developed a knowledge-creation model based on the premise that knowledge-creation activities build up an organization's core competencies. Due to the fact that in today's environment conditions change rapidly, companies must be able to continuously create new technological knowledge internally [72]. Many practitioners are of the perception that strategy depends on learning, and learning depends on capabilities. These concepts were popularized by C. K. Prahalad and Gary Hamel through some of their publications including "The Core Competence of the Corporation" and "Strategy as Stretch and Leverage" in 1990 and 1993 respectively [73] [74] together with a book published in 1994 called "Competing for the Future" [75]. They postulated that dynamic capabilities approach consider strategic management as a collective learning process. This is aimed at developing and exploiting distinctive competences that makes imitation highly impossible. Their concept fits into the learning school of strategy formulation naturally [31].

\subsubsection{Chaos Theory}

Chaos theory is a scientific principle describing the unpredictability of systems. Most fully explored and recognized during the mid-to-late 1980s, its premise is that systems sometimes reside in chaos, generating energy but without any predictability or direction. These complex systems may be weather patterns, ecosystems, water flows, anatomical functions, or organizations. An arena within which chaos theory is useful is that of organizations. Applying chaos theory to organizational behavior allows theorists to take a step back from the management of day-to-day activities and see how organizations function as unified systems. An organization is a classic example of a nonlinear system. This means that it is a system in which minor events have the potential to set off grave consequences or chain reactions, and major changes may have little or no effect on the system whatsoever. In order to exploit the chaotic quality of an organization, one needs to try to see the organizational shape that emerges from a distance. Instead of pinpointing causes in the organization for organizational problems, the company is better served, according to chaos theory, by looking for organizational patterns that lead to certain 


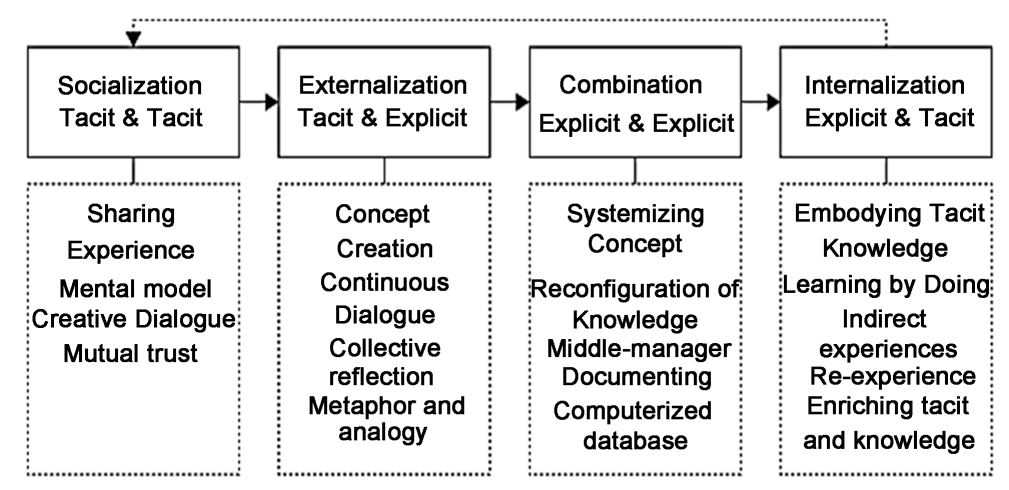

Figure 8. Knowledge creation practices and key actions. Source: Song (2008) p. 92.

types of behavior within the organization. Organizational expectations for acceptable behavior, and the degree of freedom with which individuals are allowed to work, shape the way a company's problems and challenges are handled by its members. By allowing people and groups within an organization some autonomy, businesses encourage the organization to organize itself, enacting multiple iterations of its own functioning until the various pieces of the organization can work together most effectively. An organization that encourages this type of management has been termed a fractal organization, one that trusts in natural organizational phenomena to order itself [76]. The chaos theory therefore supports the basis of the learning school which encourages participatory decision making process.

\subsection{Levels of Organizational Learning}

Organizational learning is the ability of the institution as a whole to discover errors and correct them, and to change the organization's knowledge base and values so as to generate new problem-solving skills and new capacity for action [77]. Various literature and authors suggest three general learning styles (Single-loop, Doubleloop and Duetero) [78]-[80]. The three types are discussed in details below [81] [82]:

\subsubsection{Single-Loop Learning}

The first level of organizational learning is single-loop learning. Single-loop learning solves the presenting problems. It occurs when people attempt to correct the mismatches between actions and intended outcomes simply by changing their actions when the governing values or assumptions that underlie those actions are not open to change. Single-loop learning as depicted in Figure 9, asks a one-dimensional question to elicit a one-dimensional answer. It addresses a difficulty but ignores a more fundamental problem, i.e. why the mismatch or error existed in the first place. Single-loop learning is present when goals, values, frameworks and to a significant extent, strategies are taken for granted.

\subsubsection{Double-Loop Learning}

Double-loop learning takes an additional step or, more often than not, several additional steps. It occurs when, in addition to detection and correction of errors, the organization is involved in the questioning and modification of existing norms, procedures, policies, and objectives. In other words, double-loop learning as depicted in Figure 10, asks questions not only about objective facts but also about the reasons and motives behind those facts. Double-loop learning provides opportunities for discontinuous steps of improvement where reframing a problem can bring about radically different potential solutions [83]. Therefore organizational problem-solving capability is increasing when double-loop learning takes place.

\subsubsection{Deutero Learning}

The third, and highest organizational learning level of the model is deutero-learning, which can be regarded as learning to learn. The members of an organization ask more and more fundamental questions about their organization, reflect on and inquire previous contexts for learning. This model of organizational learning as shown in Figure 11 [84] [85] refers to the organizational capacity to set and solve problems and to design and redesign 


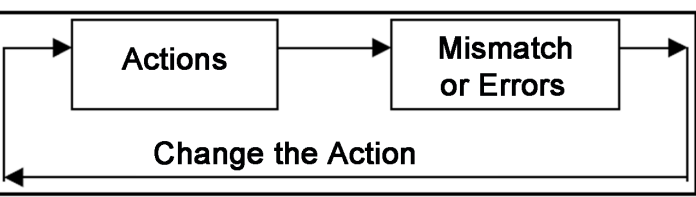

Figure 9. Single-loop learning. Source: Argyris (1990).

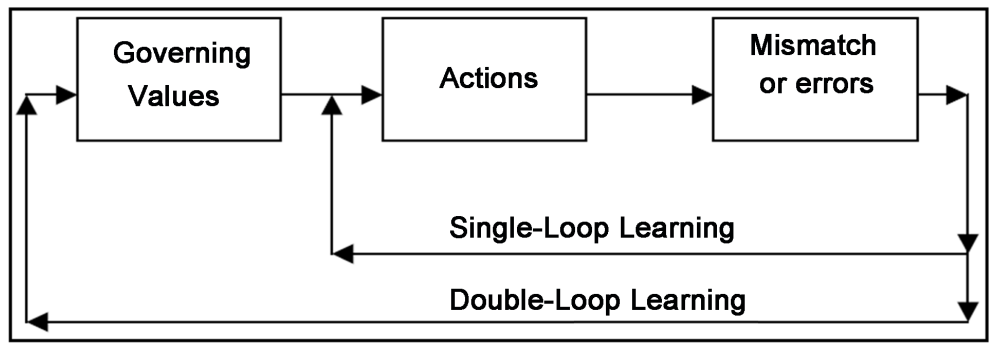

Figure 10. Double-loop learning. Source: Argyris (1990).

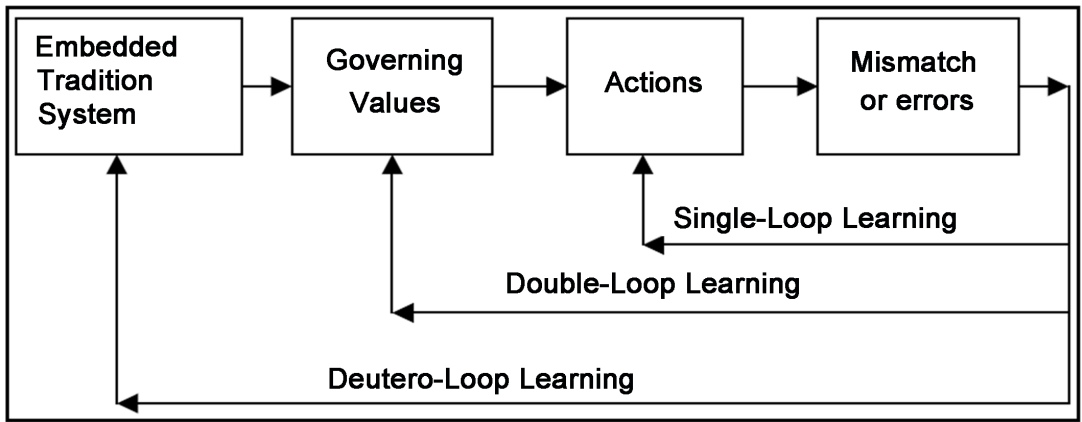

Figure 11. Deutero learning. Source: Nielsen (1996), 36. Quoted in Seo (2003).

policies, structures, and techniques in the face of constantly changing assumptions about self and environment. There can occur all three levels in organizational learning but the second and the third learning level are assumed to be of critical importance to enhance the survival and success of organizations.

\subsection{New Directions for Strategic Learning}

Senge in 1992 described the core of a learning organization's work as based upon five learning disciplines which represented lifelong programs of both personal and organizational learning and practice [86]. These five disciplines of learning chart the path for new directions for strategic learning as shown in Figure 12 [87]. The five disciplines have been briefly discussed below [88]:

- Personal Mastery-individuals learn to expand their own personal capacity to create results that they most desire. Employees also create an organizational environment that encourages all fellow employees to develop themselves toward the goals and purposes that they desire.

- Mental Models - this involves each individual reflecting upon, continually clarifying, and improving his or her internal pictures of the world, and seeing how they shape personal actions and decisions.

- Shared Vision - this involves individuals building a sense of commitment within particular workgroups, developing shared images of common and desirable futures, and the principles and guiding practices to support the journey to such futures.

- Team Learning - this involves relevant thinking skills that enable groups of people to develop intelligence and an ability that is greater than the sum of individual members' talents.

- Systems Thinking - this involves a way of thinking about, and a language for describing and understanding forces and interrelationships that shape the behavior of systems. This discipline helps managers and employees alike to see how to change systems more effectively, and to act more in tune with the larger processes of the natural and economic world. 


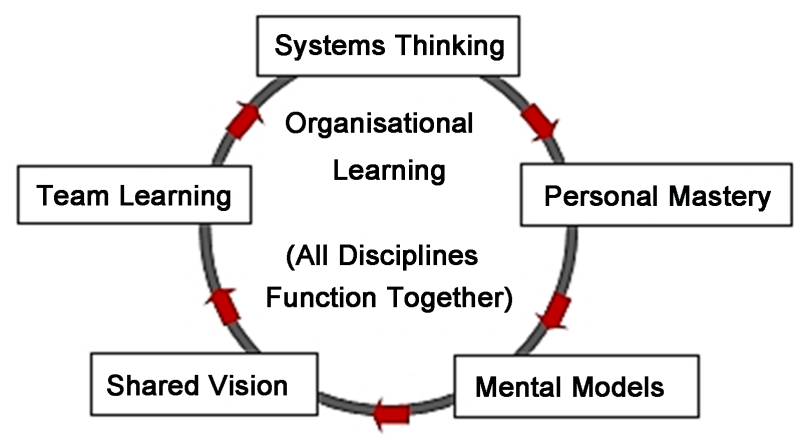

Figure 12. Senge's five disciplines. Source: School That Learn (2000) Doubleday.

\section{Criticisms and Limitations of the Learning School}

The learning school of strategy formulation has been criticized and certain limitations identified by some authors and available literature as follows [37]:

The critique of learning school highlights the fact that for rapid changes in an environment, the strategy has to be flexible and methodological. Another critique is the concept of "learning myopia”, the propensity to overlook failures or long terms. It is not clear what information is needed. As Shekhar in 2009 said, "Every strategy has some inherent weakness due to the conditions under which it is formulated" [89]. Some researchers go beyond and believe that learning school may form a structure that is no longer required. Organizations should not only be on learning mode but also shall evaluate the learning in order to get work done. The main criticism of the school is that it is formulated under specific conditions, which may not be easy to change and therefore the school itself may not be adapted to the rapid environmental changes.

The other criticism is that being obsessed with learning, the strategy may overlook failures and some essential aspects, as it happened with Nokia vs. Motorola. The school depends on the conditions under which the strategy is formulated. The conditions are subject to changes and the strategy has to be flexible to respond to these rapid changes. More critics come from the "tendency to overlook failures, distant futures and distant places" [90].

There is also criticism that learning process can be "purposeless and anti-strategic" which may result in manipulation and misinterpretation and not "strategic thinking”. The learning process may be too slow and when the formation is ready it may no longer be valid or required. Some strategists suggest the formation should be not only out of learning but also out of exploitation of learning. Shekhar highlighted the Mintzberg's concept of "logical incrementalism" in the learning school, arguing that Mintzberg described it as "unclear or ambiguous" during formation of strategic vision. Shekhar described the school as a "synthesis" that is supported by a successful example of strategic actions [89].

In addition, Mintzberg was criticized for not analyzing every single aspect, including "scenario planning” approach with integrated internal and external factors. He also was criticized for lowing managerial and strategist's values and for not defining the issue of social responsibility. The school is lacking in emphasizing on the future. From one hand, it refers to the business reality and shapes the future through experience. From the other hand, one of the arguments of learning school is that the future is unpredictable and this argument undervalues the effect of learning, showing that there are some possibilities for trials and errors. Pelling criticized the school for being too idealistic and confusing "global strategy with localized tactics". His argument was that the learning school confuses "learning with response and it does not have any useful concept of active sensing". The author accused the school of being too dialectical with "little capacity to self-reflection or self-assessment". Pelling argues that the school grounds its philosophy on pragmatic learning where anomalies may occur and responses to these anomalies do not add any values or usefulness. Although he mentioned that the school has many useful features, he strongly argued that it is anti-judgment and unscientific [40].

Another limitation of such school is that the school can lead without strategy or just with tactical maneuvering, applying strategic drift. The strategy is quite questionable during crisis and is not useful in stable context. Taking many sensible small steps does not necessarily add up to sound total strategy [91].

Finally, learning can be expensive. It takes time, sometimes resulting in endless meetings and floods of electronic mail; it goes off in all sorts of funny directions; resources must be invested in false starts; people have to 
be convinced of the benefits of one initiative over another; and the organization may be forced to bounce around repeatedly, and so pay the price of not settling down quickly enough to concentrate its resources. Managers have to focus their learning; they need to know what they are actually learning about. A real learning organization also worries about unnecessary learning [31].

\section{Contribution of the Learning School}

The following are some of the contributions of the learning school despite the aforementioned criticisms and limitations [91] [92]:

- It provides simple methods that help to explain complex phenomenon.

- It promotes and encourages decentralization which forms the basis of grass roots model of strategy formulation.

- There is no need to have an omnipotent leader which forms the bed rock of centralization.

- It helps us to see strategy as a learning process through collaboration of both individual and collective efforts.

- The learning school helps organizations to create and come out with novel and interesting strategies like Honda.

- The learning school strategy is largely practiced in professional organizations.

- It can be combined with emergent view.

\section{Application of the Learning School by Honda}

\subsection{Brief Background of Honda}

Honda was founded in the late 1940s as Japan struggled to rebuild following the Second World War Company founder Soichiro Honda first began manufacturing piston rings before turning his attention to inexpensive motorcycles. Mr. Honda always had a passion for engineering, and this became evident by the wild sales success of his motorcycles in the 1960s and by competing head-to-head against the world's best on racetracks. Today, Honda is a juggernaut, offering class-leading machines in most every category [93].

\subsection{Honda's Case}

Japanese automobile and electronics companies have been the focus of much analysis by western management theorists since their successful entry into world markets during the 1970s and 1980s. Western management theorists sought to explain how these companies were able to penetrate markets previously dominated by entrenched North American and European firms, as well as to identify transferable lessons from their success [94]. The Honda Motor Company attracted the particular attention of strategic management theorists, in both the academic and consulting worlds such as Hamel and Prahalad [76], Boston Consulting Group [95], Pascale [96], Quinn [97] [98], Mintzberg [99]-[102], Abbeglen and Stalk [103], Stalk and Hout [104], and Stalk, Evans and Shulman [105]. Pascale's account of how Honda really entered the American motorcycle market compared with claims by the Boston Consulting Group provides a stunning juxtaposition of the positioning and learning schools [31]. This section therefore assesses how the businesses practices that made Honda successful support the learning school of strategy as an emergency process.

\subsubsection{The Boston Consulting Group (BCG) Account}

Some years ago, the British Government hired the Boston Consulting Group (BCG) to help explain how it was that the Japanese firms, especially Honda, so dramatically outperformed those of the UK in the markets for motorcycles in the United States. In 1959, the British had 49\% of the import market; by 1966, Honda alone had captured a 63\% share of the entire market. The BCG report was issued in 1975 and it was vintage BCG, and classic rational positioning. Therefore the report became the basis for well-known case studies written at Harvard and elsewhere and used in many American business schools to teach the students exemplary strategic behavior. The report was about experience curves and high market shares and carefully thought-out deliberate strategies, especially how a firm dedicated to low cost, using the scale of its domestic production base, attacked the American market by forcing entry through a new segment by selling small motorcycles to middle-class consumers. To quote from the BCG report: "The Japanese motorcycle industry, and in particular Honda, the market 
leader, present a [consistent] picture. The basic philosophy of the Japanese manufacturers is that high volumes per model provide the potential for high productivity as a result of using capital intensive and highly automated techniques. Their marketing strategies are, therefore, directed towards developing these high model volumes, hence the careful attention that we have observed them giving to growth and market share” [95].

\subsubsection{Pascale's "Honda Effect" Emphasizes a Strategic Learning Process}

In a direct response to the BCG study, in a 1984 academic publication [96], Pascale argued that in fact "the Japanese" view strategy differently from Americans and Europeans, and that they find a number of Western concepts, such as "portfolio theory" or the "experience curve", too formulaic, and indeed too easy to "read" (and therefore to counter) from the behaviors of competitors. Pascale's approach is to set out two different perspectives on Honda's breakthrough into the American motorcycle market in the early 1960s. The first approach is based on the BCG study, which Pascale argues has superimposed an inappropriately rationalistic interpretative framework onto Honda's actual strategy. Pascale is particularly troubled by the implication in the BCG study that Honda followed an economically driven strategy in the years around 1960 based on achieving low costs through high volume, and he quotes the first of the short fragments of the BCG report which discusses this period as cited above [95] as an example. He also, and at much greater length, then quotes a Harvard Business School case study (presented as based on the BCG analysis, yet which adds a wealth of detail, plus a bullish business school "success story" overtone which is not apparent in the original BCG study) which certainly makes Honda appear to have followed a clear and logical strategy.

The second perspective describes what Pascale terms the "organizational process" behind Honda's American success. To Pascale, Honda's story highlights miscalculation, serendipity, and organizational learning which counterpoints to the "streamlined strategy version" represented by BCG. He proceeds to describes the idiosyncratic characters and leadership of company founders Soichiro Honda and Takeo Fujisawa, the product design (rather than production process, pointedly) advantages that Honda developed, in particular the wedding of a high-tech small engine to an innovative design in the 1958 Super Cub small motorcycle. The success of this product in Japan permitted the 300,000 capacity Suzuka factory to be built and Honda to distribute it directly to US retail outlets (primarily bicycle shops), bypassing the traditional dealers. Pascale quotes Kihachiro Kawashima, one of the managers charged with exploring the US market from 1958, at length, to present a vivid firsthand impression of Honda's entry into the United States when the first sales subsidiary was opened in 1959. Kawashima recounts that there was no definite strategy in terms of how to penetrate the US market. Pascale's account is an expression of real-life strategy-making which is ignored by the "Western consultants, academics and executives" with their "preference for oversimplifications of reality and cognitively linear explanations of events". What matters, and what Pascale believes requires more research, is how organizations deal with miscalculations, mistakes and serendipity. In Pascale's view, Honda was quick to learn and react to the unexpected which ensured its success in the US market. Pascale's study of Honda counterpoised the design/planning schools of strategy. The counteraction was done as introduced an emergent/incrementalist approach to argue that the planning approach is not all it is claimed to be [106]-[108].

\subsubsection{For Mintzberg, Honda Epitomizes the Value of Learning over Planning}

Henry Mintzberg has frequently drawn on Pascale's story of the "Honda effect”; indeed he considers Pascale's study to be perhaps the most influential article published in the management literature [101]. By 1987 Mintzberg was proposing Honda as an example of a company which epitomized the way good strategy is "crafted" rather than "planned". Mintzberg refers to Pascale's account of how Honda stumbled into its enormous success in the American motorcycle market. Brilliant as its strategy may have looked after the fact, Honda's managers made almost every conceivable mistake until the market finally hit them over the head with the right formula. The Honda managers on site in America, driving their products themselves (and thus inadvertently picking up market reaction), did only one thing right: they learned, firsthand. Thus Honda's successful entry into the US motorcycle market in the early 1960s is portrayed as an example of a "grass-roots approach to strategic management" [99]. Honda is highly regarded as a company with common sense, not overly-rational, willing to learn rather than impose distant corporate views. Mintzberg argues that if Honda had in fact been "rational" in its planning it would not have attempted to sell the small motorcycles in the United States at all. The Honda case thus reveals the necessity of "emergent learning alongside deliberate planning". The problem with the BCG analysis is that it ignored the emergent learning phase which, Mintzberg argues, had to come first, prior to the 
formal planning upon which BCG concentrates. Hence while both planning and learning are necessary, learning must come first; accordingly, he concludes with a score of "1-0" for informal learning over formal planning [100].

\section{Conclusion}

Unlike the design school which denies certain important aspects of strategy formation, including incremental development and emergent strategy, the learning school embraces them [109]. The emergent strategy process is not locked on top down schema but built in bottom-top structure and can be developed from the ideas and constructions coming directly from the market reality. The participative management integer's tools like the management system control which promote the emergence of new strategy [31] [110]. One of the recommendations, according to Scott, D. Anthony and Mark Johnson is to keep the door open for all the new ideas coming from the field and not to be too rigorous with the definitions of the objectives and be able to change the lines of the strategy at any time [111]. During this revision of the strategy, it allows to alter the course of the strategy judiciously or more radically, to redesign the strategy in order to take advantage of an opportunity [112]. In the nutshell, the school emphasizes on the need for learning organizations to adopt the grassroots approach which involves all hands-on-deck phenomenon.

The learning school model offer enormous benefits to learning organizations. The strategy evolves continuously which is a very flexible approach that can be developed over time according to new resources, policy and market expectations. The learning school of strategy formulation is very efficient into fast moving market. It allows a constant development as more as the organization learns about the strategy and market situation. Since the implementation of the strategy is redefined, it forms an integral part of the strategy development process. Moreover, the fact to work in a day by day approach allows the optimal culture to emerge instead of an artificial planning process. Learning organizations can enjoy the aforementioned benefits and others by learning from Honda's success story as well as apply the following principles [113]:

- Organizations can learn as much, if not more, from failure as from success.

- A learning organization rejects the adage "if it ain't broken, don't fix it".

- Learning organizations assume that the managers and workers closest to the design, manufacturing, distribution and sale of the product often know more about these activities than their superiors and therefore their inputs must be sought and incorporated in the decision making process.

- A learning organization actively seeks to move knowledge from one part of the organization to another, to ensure that relevant knowledge finds its way to the organizational unit that needs it most.

- Learning organizations spend a lot of energy looking outside their own boundaries for knowledge.

\section{References}

[1] Okumus, F. and Roper, A. (1999) A Review of Disparate Approaches to Strategy Implementation in Hospitality Firms. Journal of Hospitality and Tourism Research, 23, 21-39. http://dx.doi.org/10.1177/109634809902300103

[2] Njagi, L. and Kombo, H. (2014) Effect of Strategy Implementation on Performance of Commercial Banks in Kenya. European Journal of Business and Management, 6, 62-67.

[3] What Is Strategy? https://bookshop.blackwell.co.uk/extracts/9780199288304_henry.pdf

[4] Von Clausewitz, K. (1982) On War (Ed. A. Rapaport). Penguin, Harmondsworth.

[5] Gray, H. (2005) Strategy and Leadership: The Developing Approach. Development and Learning in Organizations, 19, 5-7. http://dx.doi.org/10.1108/14777280510572112

[6] De Wit, B. and Meyer, R. (2004) Strategy: Process, Content, Context. 3rd Edition, Thomson Learning, London.

[7] Camillus, J.C. (2008) Strategy as a Wicked Problem. Harvard Business Review, 86, 98-101.

[8] Collis, D.J. and Rukstad, M.G. (2008) Can You Say What Your Strategy Is? Harvard Business Review, 86, 82-90.

[9] Martin, S. (2008) Strategy Development and Implementation. NHS Institute for Innovation and Improvement. http://www.qualitasconsortium.com/index.cfm/reference-material/primary-care/strategy-development/

[10] Hrebiniak, L.G. (2006) Obstacles to Effective Strategy Implementation. Organizational Dynamics, 35, 12-31. http://dx.doi.org/10.1016/j.orgdyn.2005.12.001

[11] Noble, C.H. (1999) The Eclectic Roots of Strategy Implementation Research. Journal of Business Research, 45, 119134. http://dx.doi.org/10.1016/S0148-2963(97)00231-2 
[12] Yang, L., Sun, G. and Eppler, M.J. (2008) Making Strategy Work: A Literature Review on the Factors Influencing Strategy Implementation. ICA Working Paper 2/2008.

[13] Aaltonen, P. (2003) Actions that Realize Strategy. The 19th EGOS Colloquium, Vol. 5, Copenhagen, 3-5 July 2003, $1-23$.

[14] Cohen, M.D., March, J.G. and Olsen, J.P. (1972) A Garbage Can Model of Organizational Choice. Administrative Science Quarterly, 17, 1-25. http://dx.doi.org/10.2307/2392088

[15] Cyert, R.M. and March, J.G. (1963) A Behavioral Theory of the Firm. Prentice Hall, Englewood Cliffs.

[16] Dutton, J.E. and Jackson, S.E. (1987) Categorizing Strategic Issues: Links to Organizational Action. Academy of Management Review, 12, 76-90.

[17] March, J.G. and Simon, H.A. (1958) Organizations. Wiley, New York.

[18] Sminia, H. (2009) Process Research in Strategy Formation: Theory, Methodology and Relevance. International Journal of Management Reviews, 11, 97-125.

[19] Mintzberg, H. (1978) Patterns in Strategy Formation. Management Science, 24, 934-948. http://dx.doi.org/10.1287/mnsc.24.9.934

[20] Quinn, J.B. (1980) Strategies for Change: Logical Incrementalism. Irwin, Homewood.

[21] Pettigrew, A.M. (1973) The Politics of Organizational Decision Making. Tavis-Tock, London.

[22] Mintzberg, H., Ahlstrand, B. and Lampel, J. (1998) Strategy Safari-A Guided Tour through the Wilds of Strategic Management. A TCI Book Review. http://www.consulttci.com/book_reviews/safari.html

[23] Whittington, R. (1993) What Is Strategy and Does It Matter? Routledge, London.

[24] Selsky, J.W., Goes, J. and Baburoglu, O.N. (2007) Contrasting Perspectives of Strategy Making: Applications in "Hyper” Environments. Sage Publications, Organization Studies, 28, 71-94.

[25] Porter, M.E. (1980) Competitive Strategy: Techniques for Analyzing Industries and Competitors. Free Press, New York.

[26] Barney, J. (1986) Types of Competition and the Theory of Strategy: Toward an Integrative Framework. Academy of Management Review, 11, 791-800.

[27] Ferrier, W., Smith, K.G. and Grimm, C. (1999) The Role of Competitive Action in Market Share Erosion and Industry Dethronement: A Study of Industry Leaders and Challengers. Academy of Management Journal, 42, 372-388. http://dx.doi.org/10.2307/257009

[28] Foss, N.J. and Knudsen, T. (2003) The Resource-Based Tangle: Towards a Sustainable Explanation of Competitive Advantage. Managerial and Decision Economics, 24, 291-307. http://dx.doi.org/10.1002/mde.1122

[29] Emery, F. and Trist, E. (1973) Towards a Social Ecology. Plenum, New York.

[30] Mintzberg, H. (1990) Strategy Formation: Schools of Thought. In: Frederickson, J., Ed., Perspectives on Strategic Management, Harper Business, New York, 105-237.

[31] Mintzberg, H., Ahlstrand, B. and Lampel, J. (1998) Strategy Safari: A Guided Tour through the Wilds of Strategic Management. Prentice Hall, Upper Saddle River.

[32] Kotelnikov, V. (2006) Ten Major Strategic Management Schools: A Comparative Analysis. http://www.1000ventures.com/business_guide/mgmt_inex_stategy_10schools.html

[33] The Learning School, MWF Group 1's Blog. http://group1strategic.wordpress.com/strategy-safari/the-learning-school/

[34] Rinje (2014) Project. Studymode.Com. http://www.studymode.com/essays/Project-49914330.html

[35] Lindblom, C.E. (1959) The Science of “Muddling Through". Public Administration Review, 19, 79-88. http://dx.doi.org/10.2307/973677

[36] Wrapp, H.E. (1967) Good Managers Don’t Make Policy Decisions. Harvard Business Review, 45, 91-99.

[37] Zaplatinskaia, L. (2010) Strategy Analysis through Perception of Learning and Configuration Schools. http://profi20.livejournal.com/13450.html?thread=59018

[38] Noda, T. and Bower, J.L. (1996) Strategy Making as Iterated Processes of Resource Allocation. Strategic Management Journal, 17, 159-192.

[39] Burgelman, R.A. (1983) A Process Model of Internal Corporate Venturing in the Diversified Major Firm. Administrative Science Quarterly, 28, 223-244. http://dx.doi.org/10.2307/2392619

[40] Pelling, N. (2004) Mintzberg’s Ten Schools. Kingston University Business School, Surrey, UK.

[41] Hurtado, P. (2007) On the Ethical Implications of the Relationship between Types of Research Methodologies and 
Theories of Strategy Formation. Competition Forum, 5, 220-228.

[42] Quinn, J.B. (1978) Strategic Change: Logical Incrementalism. Sloan Management Review, 20, 7-21.

[43] Sandberg, W.R. (1986) New Venture Performance: The Role of Strategy and Industry Structure. D.C. Heath, Lexington.

[44] Mintzberg, H. and Lampel, J. (1999) Reflecting on the Strategy Process. Sloan Management Review, 40, 21-30.

[45] French, S. (2009) Re-Framing Strategic Thinking: The Research-Aims and Outcomes. Journal of Management Development, 28, 205-224. http://dx.doi.org/10.1108/02621710910939604

[46] Van Eijnatten, F.M. and Putnik, G.D. (2004) Chaos, Complexity, Learning and the Learning Organization: Towards a Chaordic Enterprise. The Learning Organization, 11, 418-429. http://dx.doi.org/10.1108/09696470410548782

[47] Sugarman, B. (1997) Learning, Working, Managing, Sharing: The New Paradigm of the Learning Organization. Journal of Pedagogy, Pluralism and Practice, 1, 559-570.

[48] Argyris, C., Bellman, M. G., Blanchard, K., Block, P., Bridges, W., Deane, B., Gery, G., Juechter, W.M., Kanter, R.M., Lawler III, E.E., Peters, T., Pinchot, G., Pinchot, E., Senge, P.M., Tichy, N. and Wheatley, M. (1994) The Future of Workplace Learning and Performance. Training and Development, 48, 36-47.

[49] Garvin, D.A. (1993) Building a Learning Organization. Harvard Business Review, 71, 78-91.

[50] Senge, P. (1990) The Fifth Discipline. Doubleday, New York.

[51] Leonard-Barton, D. (1992) Core Capabilities and Core Rigidities: A Paradox in Managing New Product Development. Strategic Management Journal, 13, 111-125. http://dx.doi.org/10.1002/smj.4250131009

[52] Leonard-Barton, D. (1992) The Factory as a Learning Laboratory. Sloan Management Review, 34, $23-38$.

[53] Dutrénit, G. (2000) Learning and Knowledge Management in the Firm: From Knowledge Accumulation to Strategic Capabilities. Edward Elgar Publishing, Northampton, MA.

[54] Mintzberg, H. (1989) Mintzberg on Management: Inside Our Strange World of Organizations. Free Press, New York.

[55] Professional Judgment and Decision Making. Harvard Kennedy School. http://www.hks.harvard.edu/degrees/teaching-courses/course-listing/mld-301

[56] Wellman, J.L. (2009) Organizational Learning. Palgrave Macmillan, Basingstoke. http://dx.doi.org/10.1057/9780230621541

[57] Allee, V. (1997) The Knowledge Evolution: Expanding Organizational Intelligence. Butterworth-Heinemann, Oxford.

[58] Nonaka, I. and Takeuchi, H. (1995) The Knowledge-Creating Company: How Japanese Companies Create the Dynamics of Innovation.

[59] O’Dell, C.S., O’Dell, C., Grayson, C.J. and Essaides, N. (1998) If Only We Knew What We Know: The Transfer of Internal Knowledge and Best Practice. Free Press, New York.

[60] Sverlinger, P. (2000) Managing Knowledge in Professional Service Organizations. Technical Consultants Serving the Construction Industry, Chalmers Reproservice, Gothenburg.

[61] Szulanski, G. (2000) The Process of Knowledge Transfer: A Diachronic Analysis of Stickiness. Organizational Behavior and Human Decision Processes, 82, 9-27. http://dx.doi.org/10.1006/obhd.2000.2884

[62] Nonaka, I. (1994) A Dynamic Theory of Organizational Knowledge Creation. Organization Science, 5, 14-37. http://dx.doi.org/10.1287/orsc.5.1.14

[63] Alipour, F., Idris, K. and Karimi, R. (2011) Knowledge Creation and Transfer: Role of Learning Organization. International Journal of Business Administration, 2, 61-67.

[64] Frost, A. (2010) Knowledge Creation. http://www.knowledge-management-tools.net/knowledge-creation.html

[65] Yoon, S.W., Song, J.H. and Lim, D.H. (2009) Beyond the Learning Process and toward the Knowledge Creation Process: Linking Learning and Knowledge in the Supportive Learning Culture. Performance Improvement Quarterly, 22, 49-69. http://dx.doi.org/10.1002/piq.20060

[66] Nonaka, I., Toyama, R. and Byosiere, P. (2001) A Theory of Organizational Knowledge Creation: Understanding the Dynamic Process of Creating Knowledge. In: Dierkes, M., Antal, A.B., Child, J. and Nonaka, I., Eds., Handbook of Organizational Learning and Knowledge, Oxford University Press, New York, 491-517.

[67] Nonaka, I. (1991) The Knowledge-Creating Company. Harvard Business Review, 69, 96-105.

[68] Hoon Song, J., Kolb, J.A., Hee Lee, U. and Kyoung Kim, H. (2012) Role of Transformational Leadership in Effective Organizational Knowledge Creation Practices: Mediating Effects of Employees’ Work Engagement. Human Resource Development Quarterly, 23, 65-101. http://dx.doi.org/10.1002/hrdq.21120

[69] Song, J.H. (2008) The Key to Organizational Performance Improvement: A Perspective of Organizational Knowledge 
Creation. Performance Improvement Quarterly, 21, 87-102. http://dx.doi.org/10.1002/piq.20024

[70] Schienstock, G. (2009) Organizational Capabilities: Some Reflections on the Concept. IAREG Working Paper 1.2.C, Research Unit for Technology, Science and Innovation Studies (Tasti), University of Tampere, Tampere.

[71] Boerner, C., Macher, J.T. and Teece, D.J. (2001) A Review and Assessment of Organizational Learning in Economic Theories. In: Dierkes, M., Berthoin-Antal, A., Child, J. and Nonaka, I., Eds., Handbook of Organizational Learning and Knowledge, Oxford University Press, Oxford, 89-117.

[72] Leonard, D. (1995) Wellsprings of Knowledge: Building and Sustaining the Sources of Innovation. Harvard Business School Press, Boston.

[73] Prahalad, C.K. and Hamel, G. (1990) The Core Competence of Corporation. Harvard Business Review, 68, $79-91$.

[74] Prahalad, C.K. and Hamel, G. (1993) Stretch and Leverage. Harvard Business Review, 71, 75-84.

[75] Prahalad, C.K. and Hamel, G. (1994) Competing for the Future. Harvard Business School Press, Cambridge.

[76] Mason, W.H. Chaos Theory. Reference for Business Encyclopedia of Business, 2nd Edition, Revised By Hal P. Kirkwood Jr. http://www.referenceforbusiness.com/management/bun-comp/chaos-theory.html

[77] Probst, G. and Büchel, B. (1997) Organizational Learning: The Competitive Advantage of the Future. Prentice Hall, London.

[78] Saban, K., Lanasa, J., Lackman, C. and Peace, G. (2000) Organizational Learning: A Critical Component to New Product Development. Journal of Product and Brand Management, 9, 99-119. http://dx.doi.org/10.1108/10610420010322152

[79] Argyris, C. and Schön, D. (1978) Organizational Learning. Addison-Wesley, Reading.

[80] Liepe, Z. and Sakalas, A. (2008) The Three-Loop Learning Model Appliance in New Product Development. Inzinerine Ekonomika-Engineering Economics, 3, 73-80.

[81] Choudhury, R.S. (2013) Organizational Learning. http://www.scribd.com/doc/183565684/organizational-learning-2-pdf

[82] Argyris, C. (1990) Overcoming Organizational Defenses: Facilitating Organizational Learning. Allyn \& Bacon, Needham.

[83] Kim, D.H. (1993) The Link between Individual and Organizational Learning. Sloan Management Review, 35, 37-50.

[84] Nielsen, R.P. (1996) The Politics of Ethics: Methods for Acting, Learning, and Sometimes Fighting, with Others in Addressing Ethics Problems in Organizational Life. Oxford University Press, New York.

[85] Seo, M. (2003) Overcoming Emotional Barriers, Political Obstacles, and Control Imperatives in the Action-Science Approach to Individual and Organizational Learning. Academy of Management Learning and Education, 2, 7-21. http://dx.doi.org/10.5465/AMLE.2003.9324011

[86] Senge, P. (1992) The Fifth Discipline Field Book. Doubleday/Currency, New York.

[87] Senge, P. (2000) Schools that Learn. A Fifth Discipline Fieldboook for Educators, Parents, and Everyone Who Cares about Education. Doubleday, New York.

[88] Du Plessis, D., Du Plessis, M. and Millett, B. (1999) Developing a Learning Organization: A Case Study. Journal of Management Practice, 2, 71-94.

[89] Shekhar, V. (2009) Perspectives in Strategic Management-A Critique of Strategy Safari: The Complete Guide through the Wilds of Strategic Management. The IUP Journal of Business Strategy, 6, 43-55.

[90] Jelenc, L. (2009) Review of Theories in Strategic Management Field-Toward the Creation of Schools of Strategic Management.

[91] Ten Schools of Thought (Mintzberg). 12Manage the Executive Fast Track. http://www.12manage.com/methods_mintzberg_ten_schools_of_thought.html

[92] Milord, P. and Mkandawire, C. (2008) The Learning School Strategy Formation as an Emergent Process. Argosy University, Atlanta. http://www.slideshare.net/joshai/chapter-7-800807

[93] Used Honda Motorcycles. Motorcycle.Com (Est. 1994). http://www.motorcycle.com/classifieds/honda/motorcycles-for-sale.html

[94] Mair, A. (1999) Learning from Japan? Interpretations of Honda Motors by Strategic Management Theorists. Nissan Occasional Paper Series No. 29. http://www.nissan.ox.ac.uk/sites/sias/files/documents/nops29 0.pdf

[95] Boston Consulting Group (1975) Strategy Alternatives for the British Motorcycle Industry. HMSO, London.

[96] Pascale, R.T. (1984) Perspectives on Strategy: The Real Story behind Honda's Success. California Management Review, 26, 47-72. http://dx.doi.org/10.2307/41165080 
[97] Quinn, J.B. (1991) Honda Motor Company. In: Mintzberg, H. and Quinn, J.B., Eds., The Strategy Process: Concepts, Contexts, Cases, 2nd Edition, Prentice Hall International, Upper Saddle River, 284-299.

[98] Quinn, J.B. (1996) Honda Motor Company 1994. In: Mintzberg, H. and Quinn, J.B., Eds., The Strategy Process: Concepts, Contexts, Cases, 3rd Edition, Prentice Hall International, Upper Saddle River, 849-863.

[99] Mintzberg, H. (1987) Crafting Strategy. Harvard Business Review, 65, 66-75.

[100] Mintzberg, H. (1991) Learning 1, Planning 0 Reply to Igor Ansoff. Strategic Management Journal, 12, 463-466. http://dx.doi.org/10.1002/smj.4250120606

[101] Mintzberg, H., Pascale, R.T., Goold, M. and Rumelt, R.P. (1996) CMR Forum: The “Honda Effect” Revisited’. California Management Review, 38, 78-117. http://dx.doi.org/10.2307/41165855

[102] Mintzberg, H. (1996) Reply to Michael Goold. California Management Review, 38, 96-99.

[103] Abbeglen, J.C. and Stalk Jr., G. (1985) Kaisha, the Japanese Corporation. Basic Books, New York.

[104] Stalk Jr., G. and Hout, M. (1990) Competing Against Time. The Free Press, New York.

[105] Stalk, G., Evans, P. and Shulman, L. (1992) Competing on Capabilities: The New Rules of Corporate Strategy. Harvard Business Review, 70, 57-69.

[106] Kay, J. (1993) The Structure of Strategy. Business Strategy Review, 4, 17-37. http://dx.doi.org/10.1111/j.1467-8616.1993.tb00049.x

[107] Silbiger, S. (1994) The 10-Day MBA. Piatkus, London.

[108] Stacey, R.D. (1993) Strategic Management and Organizational Dynamics. Pitman, London.

[109] Sarbah, A. and Otu-Nyarko, D. (2014) An Overview of the Design School of Strategic Management (Strategy Formulation as a Process of Conception). Open Journal of Business and Management, 2, 231-249. http://dx.doi.org/10.4236/ojbm.2014.23029

[110] Simons, R. (1995) Levers of Control: How Managers Use Innovative Control Systems to Drive Strategic Renewal. Harvard Business School Press, Boston.

[111] Scott, D.A., Mark, W.J., Joseph, V.S. and Elizabeth, J.A. (2008) Mastering Emergent Strategies: Taking Uncertain Ideas Forward. Harvard Business Press Chapters, 4553BC-PDF-ENG, Boston.

[112] The Origins of the Strategy. http://www.ukessays.com/essays/business/the-origins-of-the-strategy-business-essay.php

[113] Strategy School 6 (2008) The Learning School. http://facilitatingimpact.blogspot.com/2008/08/strategy-school-5-learningschool.html 